\title{
Role of Laparoscopic Ileal Interposition Associated with Sleeve Gastrectomy in Management of Type 2 Diabetes Mellitus
}

\author{
AHMED E.A. EL KORDY, M.Sc.; AHMED M.I. KHALIL, M.D. and MOHAMMED M.M. OMAR, M.D. \\ The Department of General Surgery, Faculty of Medicine, Ain Shams University
}

\begin{abstract}
Background: Type 2 diabetes mellitus has reached pandemic levels with associated many co-morbidities and decrease in life expectancy. Bariatric surgery presented its value as a definitive solution for type 2 diabetes mellitus management especially with the laparoscopic surgery evolution which occurred since the 1990s. Bariatric surgery has a significant role in remission or alleviation of type 2 diabetes mellitus, weight loss, remission of comorbidities, and the improvement in the quality of life.
\end{abstract}

Aim of Study: We attempt to illustrate, through the available researches, the role of laparoscopic ileal interposition associated with sleeve gastrectomy in management of type 2 diabetes mellitus and the feasibility and efficacy of this procedure as an option in management of type 2 diabetes mellitus and assess the risk to benefit profiles.

Material and Methods: The search is carried out using the electronic national library of medicine's PubMed database plus manual reference checks of articles published on laparoscopic ileal interposition associated with sleeve gastrectomy in management of type 2 diabetes mellitus in the period between February 2019 to February 2020.

The jejuno-ileal interposition associated with sleeve gastrectomy can be an effective method used for management of type 2 diabetes mellitus in patients with BMI less than 35 $\mathrm{kg} / \mathrm{m}^{2}$

Results: The results of this procedure are promising regarding its outcome in remission of T2DM and remission of its co-morbidity diseases. The operative time of the procedure along with its reasonable post-operative hospital stay and its results in type 2 diabetes mellitus remission may present the procedure as an alternative for other more complex bariatric procedures in management of type 2 diabetes mellitus.

Conclusion: The duration time of T2DM, the drug used, the dose of the drug and the BMI of the patient affect the rate of complete remission of T2DM. The procedure can produce adequate control of hyperglycemic state in T2DM patients and satisfactory weight loss without signs of nutritional deficiencies. The procedure seems to be safe and an effective option in the management of type 2 diabetes patients with affordable risk comparing to its long term benefits.

Correspondence to: Dr. Ahmed E.A. El Kordy, E-Mail:dr.ahmedelkordi@gmail.com
Key Words: Laparoscopic ileal interposition - Sleeve gastrectomy - Metabolic surgery - Surgical management of type 2 diabetes mellitus.

\section{Introduction}

DIABETES is a debilitating, life-threatening disease accounting for the death of millions of people every year all over the world, its out breaking prevalence as well as its hazards complications such as cardiovascular disease, renal disease and infectious diseases among others makes it a major health challenge of the twenty-first century and has led to the search for novel procedures that can provide sustained glycemic control [1].

According to the last estimations about 415 million adults currently suffer from diabetes and this number is expected to rise to 642 million by 2040 [2]

The ordinary management of Type 2 Diabetes Mellitus (T2DM) includes lifestyle modulations and oral hypoglycemic drugs, insulin or combination between both [3]

While the medications aim to maintain acceptable blood glucose levels, the lifestyle modulations aim to achieve loss of weight to target the underlying pathophysiology of T2DM [4]

The significant effects of bariatric and metabolic surgery regarding loss of weight and metabolic amendment have put it as a possibility for T2DM management. By addressing many complementary pathogenic mechanisms, bariatric surgery appears to be hopeful in the reversal of the metabolic abnormalities of T2DM [5]

Ileal interposition enhance the insulin sensitivity and improve the $\mathrm{P}$-cell function in an effective way that overcomes the traditional medical therapy [6]. 
Laparoscopic ileal interposition associated with sleeve gastrectomy emerged as a choice for T2DM management due to its effect on glucose hemostasis as it intends to target the pathophysiology of the underlying mechanisms of the disease [7].

The procedure combines between the restrictive role of the sleeve gastrectomy and the malabsorptive role of the interposed ileal segment [8].

\section{Aim of the sudy:}

In this study we attempt to illustrate, through the available researches, the role of laparoscopic ileal interposition associated with sleeve gastrectomy in management of type 2 diabetes mellitus and the feasibility and efficacy of this procedure as an option in management of T2DM and assess the risk to benefit profiles.

\section{Material and Methods}

\section{I- Search strategy for identification of studies:}

The search is carried out using the electronic national library of medicine's PubMed database plus manual reference checks of articles published on laparoscopic ileal interposition associated with sleeve gastrectomy in management of type 2 diabetes mellitus in the period between February 2019 to February 2020.

The titles of the electronic results were screened to exclude duplicate studies.

Articles were identified by keywords: "Laparoscopic ileal interposition" "Sleeve gastrectomy" "Metabolic Surgery" "Surgical management of type 2 diabetes mellitus" and will be limited to research papers of all designed on human patients in English language.

Articles with no focus on laparoscopic ileal interposition associated with sleeve gastrectomy in management of type 2 diabetes mellitus will be excluded from eligibility in this review.

\section{II- Criteria for considering studies for this review:} Types of studies:

Abstracts of articles identified using the search strategy were viewed \& articles that appeared to fulfill the inclusion criteria were retrieved in full. Data of one of the outcome measures must be included in the study.

Keywords used in the search were "Laparoscopic ileal interposition" Sleeve gastrectomy" "Meta- bolic Surgery" "Surgical management of Type 2 diabetes mellitus".

\section{Types of participants:}

Participants in studies selected will be adults of age above eighteen with mean body mass index below $35 \mathrm{~kg} / \mathrm{m}^{2}$ and a diagnosis of type 2 diabetes mellitus.

\section{Types of interventions:}

Laparoscopic ileal interposition (a segment of ileum about $170 \mathrm{~cm}$ transected $30 \mathrm{~cm}$ from ileocecal valve and interposed in an isoperistaltic way into the proximal jejunum $30 \mathrm{~cm}$ from duodenoj ej unal junction) associated with sleeve gastrectomy.

\section{Types of outcome measures:}

At least one of these outcome measures was considered:

1- Clinical measures changes (symptoms-signs).

2- Laboratory measures (fasting, postprandial glucose and $\mathrm{HbAc} 1$ ).

3- Methods of treatment (Oral Hypoglycemic Agents (OHA), Insulin and both).

4- Weight loss (expressed as BMI $\mathrm{Kg} / \mathrm{m}^{2}$ ).

5- Remission or improvement of the disease and its complications.

\section{III- Methods of the review:}

Locating and selecting studies:

Abstracts of articles identified using the search strategy above were viewed $\&$ articles that appear to fulfill the inclusion criteria were retrieved in full. Data of one of the outcome measures must be included in the study.

Each article identified was reviewed and categorized into one of the following groups:

\section{Included:}

- The publications' date after the year 2000 till 2019.

- The main focus of the paper is on laparoscopic sleeve gastrectomy with ileal interposition in management of type 2 diabetes mellitus.

- Only English language studies were selected.

Excluded:

- Articles with no focus on laparoscopic sleeve gastrectomy with ileal interposition in management of type 2 diabetes mellitus.

- Studies with less than 10 patients.

- Duplicated studies. 
- Studies with no data about the outcome measures mentioned before.

- The publications' date before the year 2000.

Data extraction: Data was extracted by two reviewers and cross-checked independently.

\section{Results}

Studies description:

- All studies are prospective.

- The studies were done in India and Brazil (2 studies in each country).

\section{Population description:}

- The 4 papers included in this study contained a total of 107 patients who suffered from Type 2 Diabetes Mellitus with age, mean BMI and mean duration of T2DM described in (Table 2).

- Out of these 107 patients; 39 patients were females representing about $36 \%$ and 68 patients were males representing about $64 \%$.

Sub group analysis:

- Mean age (in years):

- In Kota et al., [9], the mean age was (47.2 \pm 8.2$)$ years.

- In Kumar et al., [10], the mean age was (48.2 \pm 9$)$ years.

- In Tinoco et al., [11], the mean age was (49.7 \pm 8.9) years.

- In Vencio et al., [12], the mean age was (54.8 \pm 7$)$ years.

- The overall mean age will be $(49.7 \pm 8.2)$ years.

- Mean duration of T2DM (in years):

- In Kota et al., [9], the mean duration of T2DM was $(10.1 \pm 9.2)$ years.

- In Kumar et al., [10], the mean duration of T2DM was $(11 \pm 5.7)$ years.

- In Tinoco et al., [11], the mean duration of T2DM was $(9.9 \pm 4.4)$ years.

- In Vencio et al., [12], the mean duration of T2DM was $(10.2 \pm 4.2)$ years.

- The overall mean duration of T2DM will be $(10.3 \pm 5.9)$ years.

\section{- Mean HbAl c (\%):}

- In Kota et al., [9], the pre-operative mean HbA $1 \mathrm{c}$ was $(9.6 \pm 2.1)$, and post-operative was $(7.2 \pm 1.5)$.
- In Kumar et al., [10], the pre-operative mean HbA1c was $(10.1 \pm 1.9)$, and post-operative was (6.7 \pm 0.6$)$.

- In Tinoco et al., [11], the pre-operative mean HbA1c was $(9.5 \pm 1.7)$, and post-operative was $(6.2 \pm 0.8)$.

- In Vencio et al., [12], the pre-operative mean HbA $1 \mathrm{c}$ was more than 7.5, and there was no post-operative change as the follow-up period was a month while $\mathrm{HbA} 1 \mathrm{c}$ is recommended every 3 months.

- The overall pre-operative mean $\mathrm{HbA} 1 \mathrm{c}$ will be (9.2 \pm 1.9$)$, and post-operative (6.9 \pm 0.96$)$.

- Mean BMI $\left(\mathrm{Kg} / \mathrm{m}^{2}\right)$ :

- In Kota et al., [9], the mean BMI pre-operative was (33.2 \pm 7.8$)$, and post-operative was (26.6 \pm $3.8)$.

- In Kumar et al., [10], the mean BMI pre-operative was (33.8 \pm 6.5$)$, and post-operative was (26.3 \pm $4.5)$.

- In Tinoco et al., [11], the mean BMI pre-operative was $(30.8 \pm 5.1)$, and post-operative was (25.7 \pm $4)$.

- In Vencio et al., [12], the mean BMI pre-operative was (29.01 \pm 3.3$)$, and post-operative was (25.8 \pm 2.9).

- The overall mean BMI $\left(\mathrm{kg} / \mathrm{m}^{2}\right)$ will be $(31.7 \pm$ 5.7) pre-operative, and (26.1 \pm 3.8$)$ post operative.

\section{Laboratory measures changes:}

- Mean HbAl c (\%):

- In Kota et al., [9], the pre-operative mean HbA 1c was $(9.6 \pm 2.1)$, and post-operative was $(7.2 \pm 1.5)$.

- In Kumar et al., [10], the pre-operative mean HbA1c was $(10.1 \pm 1.9)$, and post-operative was $(6.7 \pm 0.6)$.

- In Tinoco et al., [11], the pre-operative mean $\mathrm{HbA} 1 \mathrm{c}$ was $(9.5 \pm 1.7)$, and post-operative was $(6.2 \pm 0.8)$.

- In Vencio et al., [12], the pre-operative mean HbA $1 \mathrm{c}$ was more than 7.5, and there was no post-operative change as the follow-up period was a month while $\mathrm{HbA} 1 \mathrm{c}$ is recommended every 3 months.

- The overall pre-operative mean $\mathrm{HbA} 1 \mathrm{c}$ will be (9.2 \pm 1.9$)$, and $(6.9 \pm 0.96)$ post-operative. 
Table (1): Studies included description.

\begin{tabular}{lcccll}
\hline Author & Year & Study design & Country & Study Center & Study duration \\
\hline Kota et al., [9] & 2011 & A prospective study & India & Single Center & From February 2008 to July 2011 \\
Kumar et al., [10] & 2009 & A prospective study & India & Single Center & From January 2008 to October 2009 \\
Tinoco et al., [11] & 2011 & A prospective study & Brazil & Single Center & From March 2009 to March 2010 \\
Vencio et al., [12] & 2011 & A prospective study & Brazil & Single Center & No available data* \\
\hline
\end{tabular}

* No available data of the parameter in the study.

Table (2): Population description.

\begin{tabular}{|c|c|c|c|c|c|c|}
\hline \multirow{2}{*}{ Author } & \multirow{2}{*}{$\begin{array}{l}\text { No. of } \\
\text { patient }\end{array}$} & \multicolumn{2}{|c|}{ Gender } & \multirow{2}{*}{ Age (in years) } & \multirow{2}{*}{$\begin{array}{c}\text { Mean BMI } \\
\left(\mathrm{kg} / \mathrm{m}^{2}\right)\end{array}$} & \multirow{2}{*}{$\begin{array}{l}\text { Mean duration } \\
\text { of T2DM } \\
\text { (in years) }\end{array}$} \\
\hline & & Male & Female & & & \\
\hline Kota et al., [9] & 43 & $25(58.2 \%)$ & $18(41.8 \%)$ & $29-66 *-47.2 \pm 8.2 * *$ & $33.2 \pm 7.8 * *$ & $10.1 \pm 9.2 * *$ \\
\hline Kumar et al., [10] & 10 & $4(40 \%)$ & $6(60 \%)$ & $34-62 *-48.2 \pm 9 * *$ & $33.8 \pm 6.5^{* *}$ & $11 \pm 5.7 * *$ \\
\hline Tinoco et al., [11] & 30 & $20(66.7 \%)$ & $10(33.3 \%)$ & $33-68 *-49.7 \pm 8.9 * *$ & $30.8 \pm 5.1 * *$ & $9.9 \pm 4.4 * *$ \\
\hline Vencio et al., [12] & 24 & $19(79.2 \%)$ & $5 \quad(20.8 \%)$ & $42-64 *-54.8 \pm 7 * *$ & $29.01 \pm 3.3 * *$ & $10.2 \pm 4.2 * *$ \\
\hline
\end{tabular}

*: Data expressed as median with range (minimum - maximum). $\quad * *$ : Data expressed as mean \pm standard deviation (SD).

Table (3): Subgroup analysis.

\begin{tabular}{|c|c|c|c|c|c|c|c|}
\hline \multirow{2}{*}{ Author } & \multirow{2}{*}{$\begin{array}{c}\text { Age } \\
\text { (in years) }\end{array}$} & \multirow{2}{*}{$\begin{array}{l}\text { Mean duration } \\
\text { of T2DM } \\
\text { (in years) }\end{array}$} & \multicolumn{2}{|c|}{ Mean HbA1c (\%) } & \multicolumn{2}{|c|}{ Weight loss $\left(\mathrm{BMI} \mathrm{kg} / \mathrm{m}^{2}\right)$} & \multirow{2}{*}{ Methods of treatment } \\
\hline & & & Pre. & Post. & Pre. & Post. & \\
\hline Kota et al., [9] & $47.2 \pm 8.2 *$ & $10.1 \pm 9.2^{*}$ & $9.6 \pm 2.1 *$ & $7.2 \pm 1.5$ & $33.2 \pm 7.8^{*}$ & $26.6 \pm 3.8 *$ & $\begin{array}{l}\mathrm{OHA}^{* *} 21 \\
\text { Insulin } 10 \\
\mathrm{OHA}^{* *} \& \text { Insulin } 12\end{array}$ \\
\hline Kumar et al., [10] & $48.2 \pm 9^{*}$ & $11 \pm 5.7 *$ & $10.1 \pm 1.9^{*}$ & $6.7 \pm 0.6$ & $33.8 \pm 6.5^{*}$ & $26.3 \pm 4.5^{* *}$ & $\begin{array}{l}\mathrm{OHA}^{* *} 5 \\
\mathrm{OHA}^{* *} \& \text { Inslin } 5\end{array}$ \\
\hline Tinoco et al., [11] & $49.7 \pm 8.9 *$ & $9.9 \pm 4.4^{*}$ & $9.5 \pm 1.7 *$ & $6.2 \pm 0.8$ & $30.8 \pm 5.1 *$ & $25.7 \pm 4.0^{*}$ & $\mathrm{OHA}^{* *} \&$ OR Insulin 30 \\
\hline Vencio et al., [12] & $54.8 \pm 7 *$ & $10.2 \pm 4.2 *$ & $>7.5$ & 7.5 & $29.01 \pm 3.3 *$ & $25.8 \pm 2.9 *$ & OHA** 9, Insulin 15 \\
\hline Overall mean & $49.7 \pm 8.2 *$ & $10.15 \pm 6.4^{*}$ & $9.15 \pm 1.5^{*}$ & $6.9 \pm 0.9 *$ & $31.6 \pm 5.9^{*}$ & $26.1 \pm 3.7^{*}$ & $\begin{array}{l}\text { OHA**35, Insulin } 25 \\
\text { OHA \& OR Insluin } 47\end{array}$ \\
\hline
\end{tabular}

*: Data expressed as mean \pm standard deviation (SD). $\quad$ **: OHA: Oral Hypoglycemic Agents.

Table (4): Laboratory measures changes.

\begin{tabular}{|c|c|c|c|c|c|c|}
\hline \multirow{2}{*}{ Author } & \multicolumn{2}{|c|}{ Fasting plasma glucose (mg/dl) } & \multicolumn{2}{|c|}{ 2h. post prandial (mg/dl) } & \multicolumn{2}{|c|}{ Mean HbA1c $(\%)$} \\
\hline & Pre. & Post. & Pre. & Post. & Pre. & Post. \\
\hline Kota et al., [9] & $184.8 \pm 50.2 *$ & $119.6 \pm 21.3 *$ & $292.6 \pm 85.5^{*}$ & $162.1 \pm 40.2 * *$ & $9.6 \pm 2.1 * *$ & $7.2 \pm 1.5^{*}$ \\
\hline Kumar et al., [10] & $202.5 \pm 37.5 *$ & $116 \pm 12.3 *$ & $296.5 \pm 47.1 *$ & $155.9 \pm 23.7 * *$ & $10.1 \pm 1.9^{* *}$ & $6.7 \pm 0.6 * *$ \\
\hline Tinoco et al., [11] & $201 \pm 78.5^{*}$ & $99.6 \pm 19.7 *$ & No available data** & No available data** & $9.5 \pm 1.7 * *$ & $6.2 \pm 0.8^{*}$ \\
\hline Vencio et al., [12] & $202 \pm 43.4^{*}$ & $127.7 \pm 23.8 *$ & $251.3 \pm 87.2 *$ & $151.8 \pm 52.7 *$ & $>7.5 *$ & $7.5 *$ \\
\hline Overall mean & $194.9 \pm 55.4^{*}$ & $115.5 \pm 20.6^{*}$ & $279.9 \pm 81 *$ & $158.1 \pm 41.9^{*}$ & $9.15 \pm 1.5^{*}$ & $6.9 \pm 0.9 *$ \\
\hline
\end{tabular}

*: Data expressed as mean \pm standard deviation (SD). $\quad * *$ : The parameter has no available data in the study.

\section{Discussion}

The outraging prevalence of T2DM as well as its co-morbidities and mortality makes it a worldwide problem needs a definitive solution [13].

Bariatric and metabolic surgery became an accepted solution for the management of T2DM with efficient results on the disease and its complications [14].
The laparoscopic jejuno-ileal interposition associated with sleeve gastrectomy showed significant results in the management of T2DM [15]

All included studies focused on the influence of laparoscopic jejuno-ileal interposition associated with sleeve gastrectomy on T2DM management expressed in the improvement in the laboratory measures and the weight loss expressed in the reduction of BMI of patients after the operation 
and the procedure effect on the associated comorbidity diseases.

In this study the overall percentage of males was $64 \%$ and of females was $36 \%$.

Kota et al., [9] found that T2DM remission was significant after surgery, with 20 out of 43 patients has a complete remission and the rest of the patients showing more than $80 \%$ reduction in diabetes drug requirement.

There were considerable statistical improvements in laboratory measures (fasting blood glucose, 2-hour post prandial blood glucose, and $\mathrm{HbA} 1 \mathrm{C})$.

A considerable total body weight loss ranging between 15 and $30 \%$ is noticed in all patients.

Patients with associated complications shows improvement in their complications.

In patients with hypertension, remission is observed in 27/30 (90\%).

In patients with microalbuminuria there was marked reduction post-operatively.

Kumar et al., [10] found that T2DM control was good following surgery, there was remission of diabetes in seven patients and significant improvement in the remaining three patients proved with the statistical improvements in laboratory measures (fasting blood glucose, 2-hour post prandial blood glucose, and HbA1C).

A considerable total body weight loss ranging between $15 \%$ and $30 \%$ is noticed in all patients.

Patients with associated complications shows improvement in their complications.

All patients showed hypertension remission.

In patients with microalbuminuria improvement noticed in all patients.

Tinoco et al., [11] found that 24 patients out of $30(80 \%)$ showed remission during the 6-18-month follow-up period, with no longer required antidiabetic medication.

The remaining 6 patients (20\%) showed significant improvement after surgery, although medication was still required.

Although the BMI values before and after surgery were statistically significant, the procedure did not induce excessive weight loss.
Vencio et al., [12] a significant improvement in insulin sensitivity and insulin secretion.

All subjects show improvement in drug administrated and doses.

There were significant statistical improvements in laboratory measures (fasting blood glucose and 2-hour post prandial blood glucose), while there was no change in $\mathrm{HbA} 1 \mathrm{c}$ because the follow-up period was one month and $\mathrm{HbA} 1 \mathrm{c}$ is recommended after three months.

BMI values after surgery were statistically significant and showed a mean total body weight loss about $11.1 \%$.

In this study, it is found that the laparoscopic jejuno-ileal interposition associated with sleeve gastrectomy gives significant and remarkable effects on both T2DM and its co-morbidity diseases with a suitable operation time affordable postoperative hospital stay and the complications related to surgery were minor in the study.

In this study we found that;

- The overall mean BMI $\left(\mathrm{kg} / \mathrm{m}^{2}\right)$ was $(31.7 \pm 5.7)$ pre-operative, and became (26.1 \pm 3.8$)$ postoperative.

- The overall mean HbA1c (\%) pre-operative was (9.2 \pm 1.9$)$, and became $(6.9 \pm 0.96)$ post-operative.

- The overall mean fasting blood glucose was (197.6 \pm 52.4$)$ pre-operative, and became (115.7 \pm $19.3)$ post-operative.

- Regarding the available data of the studies, the overall mean 2-hour post prandial in the study will be $(280.1 \pm 73.3)$ pre-operative, and (156.6 \pm 38.9) post-operative.

Which shows a remarkable improvement in the glycemic control expressed in the improvement of laboratory measurements.

Pre-operative, of 107 patients in the study, 35 patients used oral hypoglycemic agents, 25 used insulin and 47 used a combination of both, while post-operative of 107 patients in the study, 51 patients show complete remission, oral hypoglycemic agents were used by 40 patients, insulin used by 15 patients with lower doses and combination of OHA \& insulin by 1 patient.

Which shows a significant improvement in the type of drugs used and the doses.

As a regard to the available data of the studies the overall mean operative time was $(225.8 \pm 55.2)$ minutes, the mean hospital stay was $(4.1 \pm 0.7)$ days. 
Which makes the procedure affordable comparing to its long term benefits.

\section{Conclusion:}

T2DM is a pandemic disease with its serious complication, its management became challenging especially in patients with long duration of T2DM.

Bariatric surgery emerged as suitable management option.

Laparoscopic jejuno-ileal interposition associated with sleeve gastrectomy shows efficient results in management of T2DM.

From this study, we concluded that the duration time of T2DM, the drug used, the dose of the drug and the BMI of the patient affect the rate of complete remission of T2DM.

The procedure can produce adequate control of hyperglycemic state in T2DM patients and satisfactory weight loss without signs of nutritional deficiencies.

The procedure seems to be safe and an effective option in the management of type 2 diabetes patients with affordable risk comparing to its long term benefits.

Further long-term data from a larger number of patients and a longer follow-up period is necessary to define the role of this procedure in T2DM management and asses the procedure feasibility.

\section{References}

1- HARDING J.L., PAVKOV M.E., MAGLIANO D.J., SHAW J.E. and GREGG E.W.: Global trends in diabetes complications: A review of current evidence. Diabetologia, 62: 3-16, 2018.

2- OGURTSOVA K., Da ROCHA FERNANDES J.D., HUANG Y., LINNENKAMP U., GUARIGUATA L., CHO N.H. and MAKAROFF L.E.: IDF Diabetes Atlas: Global estimates for the prevalence of diabetes for 2015 and 2040. Diabetes Research and Clinical Practice, 128 : 40-50, 2017.

3- CHATTERJEE S., KHUNTI K. and DAVIES M.J.: Type 2 diabetes. The Lancet, 389 (10085): 2239-51, 2017.

4- TSILINGIRIS D., KOLIAKI C. and KOKKINOS A.: Remission of Type 2 Diabetes Mellitus after Bariatric Surgery: Fact or Fiction? International Journal of Environmental Research and Public Health, 16 (17): 3171, 2019.

5- RUBINO F., NATHAN D.M., ECKEL R.H., SCHAUER
P.R., ALBERTI K.G., ZIMMET P.Z., DEL PRATO S., JI L., SADIKOT S.M., HERMAN W.H., AMIELA S.A., KAPLANB L.M., TARONCHER-OLDENBURG G. and CUMMINGS D.E.: Metabolic Surgery in the Treatment Algorithm for Type 2 Diabetes: A Joint Statement by International Diabetes Organizations. Obesity Surgery, 27 (1): 2-21, 2016

6- MINGRONE G., PANUNZI S., De GAETANO A., GUIDONE C., IACONELLI A., LECCESI L., NANNI G., POMP A., CASTAGNETO M., GHIRLANDA G. and RUBINO F.: Bariatric Surgery Versus Conventional Medical Therapy for Type 2 Diabetes. Survey of Anesthesiology, 57 (1): 24-5, 2013.

7- DePAUlA A.L., STIVAL A.R., DePAULA C.C. L., HALPERN A. and VENCIO S.: Surgical Treatment of Type 2 Diabetes in Patients with BMI Below 35: Midterm Outcomes of the Laparoscopic Ileal Interposition Associated with a Sleeve Gastrectomy in 202 Consecutive Cases. Journal of Gastrointestinal Surgery, 16 (5): $967-$ 76, 2012.

8- UGALE S., VENNAPUSA A., KATAKWAR A. and UGALE A.: Laparoscopic bariatric surgery-current trends and controversies. Annual Laparoscopic Endoscopic Surgery, 2: 154, 2017.

9- KOTA S., GUPTA N., KUMAR K.V.S.H., UGALE S., NAIK V. and MODI K.: Ileal interposition with sleeve gastrectomy for treatment of type 2 diabetes mellitus. Indian Journal of Endocrinology and Metabolism, 16 (4): 589-98, 2012.

10- KUMAR K.V.S.H., UGALE S., GUPTA N., NAIK V., KUMAR P., BHASKAR P. and MODI K.D.: Ileal Interposition with Sleeve Gastrectomy for Control of Type 2 Diabetes. Diabetes Technology \& Therapeutics, 11 (12): 785-9, 2009.

11- TINOCO A., EL-KADRE L., AQUIAR L., TINOCO R. and SAVASSI-ROCHA P.: Short-Term and Mid-Term Control of Type 2 Diabetes Mellitus by Laparoscopic Sleeve Gastrectomy with Ileal Interposition. World Journal of Surgery, 35 (10): 2238-44, 2011

12- VENCIO S., STIVAL A., HALPERN A., DePAULA C.C.L. and DePAULA A.L.: Early Mechanisms of Glucose Improvement following Laparoscopic Ileal Interposition Associated with a Sleeve Gastrectomy Evaluated by the Euglycemic Hyperinsulinemic Clamp in Type 2 Diabetic Patients with BMI below 35. Digestive Surgery, 28 (4): 293-8, 2011.

13- HERMAN W.H.: The global agenda for the prevention of type 2 diabetes. Nutrition Reviews, 75 (suppl 1): 138, 2017.

14- FRÜHBECK G.: Bariatric and metabolic surgery: A shift in eligibility and success criteria. Nature Reviews Endocrinology, 11 (8): 465-77, 2015.

15- UGALE S.M. and A CELIK A.: Ileal Interposition with Sleeve Gastrectomy for Type 2 Diabetes Mellitus and Metabolic Syndrome. Obesity, Bariatric and Metabolic Surgery, 58 (2): 547-54, 2016. 


\section{دور مداخلة اللفائفى المصاحبة لتكمييم المعدة بالمنظار

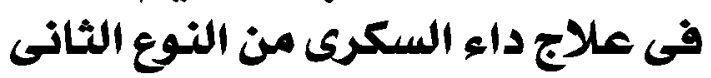

الخلفية: آصبح داء السكرى من النوع الثانى واحداً من آكثر الآمراض إنتشاراً عالمياً كما تعد مضاعفاته آحد آهم آسباب الوفاة به.

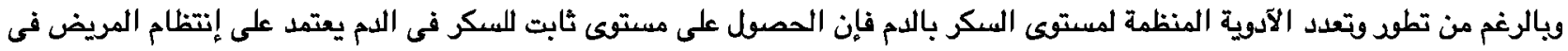
تناول العلاج وسلوكياته الغذائية.

الهدف: توضيح تآثير عملية مداخلة اللفائفى المصاحبة لتكميم المعدة بالمنظار على مستهى الآمعاء الصائمة على مرضى داء السكرى من النوع الثانى. المواد والآساليب: هذه الدراسة عبارة عن مراجعة منهجية لدراسة تآثير مداخلة اللفائفى المصاحبة لتكميم المعدة بالمنظار فى علاج داء

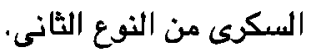

يتم البحث عن طريق قاعدة بيانات المكتبة الإلكترونية الوطنية للطب (بب ميد) بالإضافة للمراجعة اليدوية للمقالات المنشورة عن مداخلة اللفائفى المصاحب لتكميم المعدة بالمنظار فى التحكم بداء السكرى من النوع الثانى.

يتم فصص النتائج الإلكترونية بالعنوان لإستبعاد الدراسات المكررة.

المقالات يتم التعرف عليها عن طريق الكلمات الدالة الآتية: مداخلة اللفائفى بالمنظار - تكميم المعدة - جراحات الآيض - التدخل الجراحى فى علاج داء السكرى من النوع الثانى والتى تم إجرائها على الإنسان فقط.

وتكن الرسائل المتضمنة فى البحث باللغة الإنجليزية فقط.

المقالات التى لا تركز مداخلة اللفائفى المصاحب لتكميم المعدة بالمنظار فى التحكم بداء السكرى من النوع الثانى سيتم إستبعادها. النتائج: تستهدف هذه الجراحة الفسيولوجيا المرضية المصاحبة للمرض ذاته. ويعد من خصائص هذه الجراحة آنها توفر إحتكاك اللغذاء

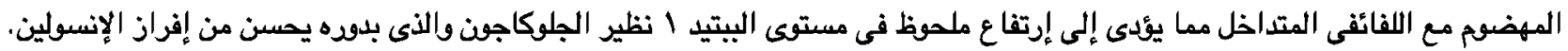

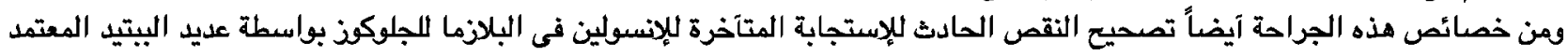

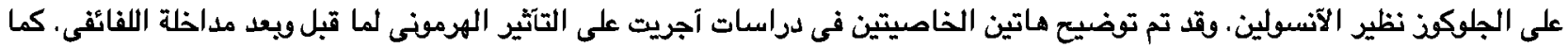
وجد آن هذه الجراحة تعمل على تحسين مقاومة الإنسولين.

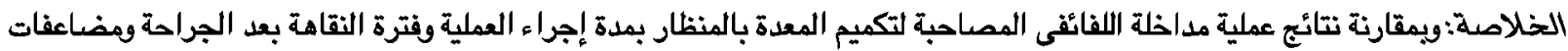

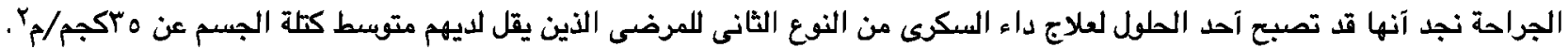

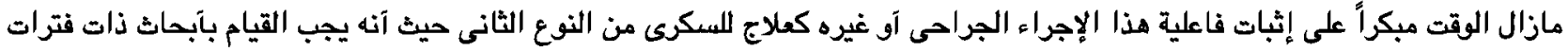
متابعة آطول وعلى عدد آكبر من المرضى. 